\title{
Influence of some cological features of the adult fishes on spatial distribution of their larvae near coral reefs at Hurghada, Egyptian Red Sea
}

\author{
Mohamed Abu El-Regal ${ }^{1}$; Salah G. El-Etreby'; Mohamed \\ ElKomi $^{1}$;Ashraf I. Ahmed and Michael Elliott ${ }^{3}$
}

1- National Institute of Oceanography \& Fisheries, Egypt

2- Suez Canal University, Faculty of science, Marine Science Dept. Ismailia, Egypt

3- Institute of Estuarine \& Coastal Studies, University of Hull, Hull, HU6 7RX, UK.

\begin{abstract}
The distribution of fish larvae near coral reefs can be influenced by physical 1 and biological factors. This paper aims to determine the influence of some ecological features of adult fish on the distribution of their larva stages at offshore and inshore sites. The spawning mode of the adults, their habitats and the depth of water column at which they live were investigated. Fish larval were collected from Hurghada by plankton net of $0.5 \mathrm{~mm}$ mesh size from January to December 2005. The Chi square test showed that the distribution of fish larvae in the area was dependent on the spawning mode and neither on the adult habitat nor the depth they live at. The analysis of variance ANOVA indicated that the distribution of larvae of pelagic fishes was significantly different between offshore and inshore sites. The study has provided further information on the distributional patterns of the larvae of coral reef fishes that help to understand the interrelationships among fish species during their larval stages.
\end{abstract}

Key words: fish larvae, Egypt, Red Sea, ecological features, spatial distribution

\section{INTRODUCTION}

Most marine fishes, regardless of their systematic affinities, demersal or pelagic habits, coastal or pelagic distribution, tropical or boreal ranges have pelagic larval stages (Moser et al., 1984). The understanding of where these stages spend their time is basic to all other studies on the pelagic stages. The traditional view that fish larvae are essentially passive plankton whose distribution is entirely dependent on currents has largely been discarded. Recently, review of reef fish biology has emphasized the importance of understanding the early life history of fishes in order to progress in ecological studies and management of the very complex and diverse coral reef community.

Ecological information on the distribution of larval fishes from field studies is limited because of taxonomic problems and the ecological studies of the larvae of reef fishes have been done very recently. Distribution of fish larvae 
in the coral reef has received more attention than any other aspect of their biology because the distribution is probably easily studied for the pelagic stage at least for smaller larvae (Leis, 1991a). The distribution of fish larvae can be determined by spawning behavior and spawning grounds of the adult, topography of the reef, duration of larval period, behavior of the larvae and their growth and mortality (Cushing, 1990; Leis, 1991a; Lazzari, 2001; Montgomery et al., 2001; Leis et al., 2006). The distribution of fish larvae can also be influenced by environmental factors including temperature and salinity (Houde and Zastrow, 1993; Hernandez-Miranda et al., 2003). The degree of larval dispersal affects the connectivity between reef fish populations and their dynamics. Small-scale studies on larval spatial distributions can give important information about possible retention mechanisms near adult habitat. Moreover, the study of small-scale temporal patterns of variation in the composition of assemblages can be used to determine the duration of the breeding seasons and dynamics of recruitment patterns of coastal species. Habitat selection of reef fish larvae at settlement is one of the mechanisms proposed to explain spatial patterns in the distribution of fishes and the corresponding spatial structure of the communities (Leis, 1991b). Larval fish assemblages in nearshore waters are complex, both in terms of species composition and patterns of distribution (Sponaugle et al., 2002). The structural complexity of coral reefs provides a variety of habitats, most of which support fish larvae. Coral reefs in the IndoPacific area including the Red Sea have a complex topography, hydrography and biota (Leis, 1991a).

The present study aimed at investiging the influencing of different ecological niches; habitat of the adults, the depth at which the adult lives and the spawning mode of the adult in the spatial distribution of coral reef fish larvae at Hurghada in the Egyptian Red Sea.

\section{Study area:}

\section{MATERIAL AND METHODS}

The study area at the northern part of Hurghada; on the Egyptian Red Sea was divided into inshore and offshore sites (Fig. 1). The inshore site was located in the front of the Marine Biological station, about $5 \mathrm{~km}$ north to Hurghada city. It is located at $27^{\circ} 17^{\prime} 6^{\prime \prime} \mathrm{N}$ and $33^{\circ} 46^{\prime} 22^{\prime \prime E}$. The offshore site is located near the Giftun Islands, about $10 \mathrm{~km}$ away from Hurghada. It is located at $27^{\circ} 13^{\prime} 22^{\prime \prime} \mathrm{N}$ and $33^{\circ} 55^{\prime} 40^{\prime \prime} \mathrm{E}$. Average of inshore and offshore sites were used during this study.

\section{Sampling and preservation:}

Ichthyoplankton samples were taken monthly from January to December 2005, using a $50 \mathrm{~cm}$ mouth diameter and $0.5 \mathrm{~mm}$ mesh size plankton net, provided with a flowmeter to calculate the volume of water filtered. Nets were towed horizontally at $1 \mathrm{~m}$ depth near the reef edge with a towing duration of 10 minutes and a towing speed of 1.5 knots. Samples were taken in the early morning just before sunrise and preserved on board in 5\% buffered formalin 
seawater. Three replicates were taken and the mean abundance and mean volume of water filtered were calculated. The volume of water filtered ranged from 64 $\mathrm{m}^{3}$ to133 $\mathrm{m}^{3}$. Densities of fish larvae were standardized to $1000 \mathrm{~m}^{3}$ of water.

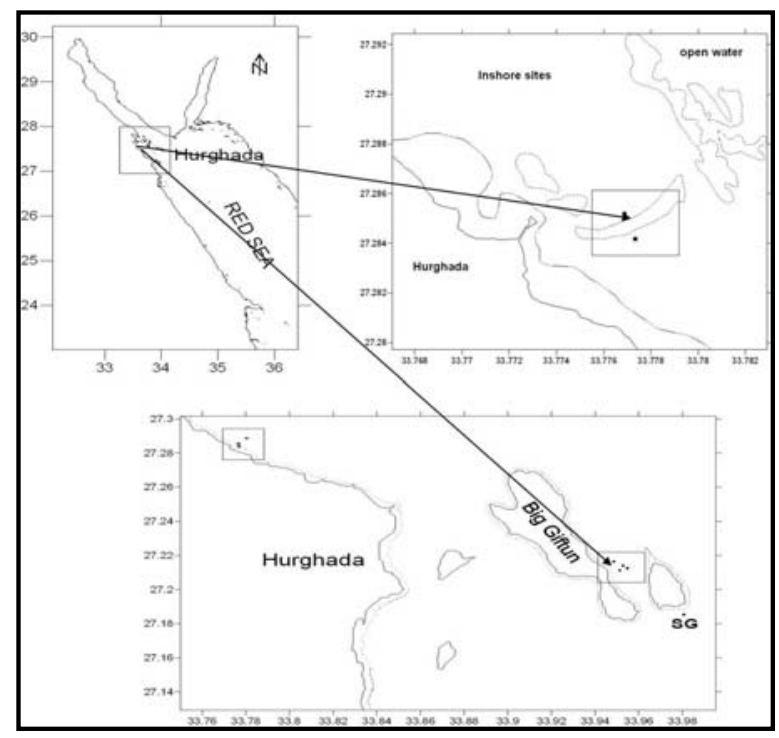

Fig.1. Map of the Red Sea and the study area showing the inshore and the offshore.

\section{Laboratory procedures:}

The samples were sorted and examined under an Olympus SZX7 stereomicroscope and then identified to the highest possible taxonomic level. The Identified taxa were categorized according to the spawning mode of the adult, the habitat of the adult, and the depth at which the adult lives. Larvae were divided according to the spawning mode of their adults into larvae from pelagic spawners, larvae from demersal spawners, larvae from brooders and larvae from live-bearers. Classification of the identified larvae into pelagic spawners, demersal spawners, brooders, and live bearers followed Brogan (1994). Based on the habitat of the adults, larvae were categorized into shorefishes (reef fishes and non-reef) and oceanic fishes. They were divided into larvae of pelagic fishes, larvae of demersal fishes and larvae of benthic fishes, according to the depth in the water column.

\section{Data analysis:}

The univariate statistics were done in SPSS v.15.0, using ANOVA to determine differences in the numbers of individuals and number of species between months and sites. All data were tested for homogeneity of variance and where the samples were not homogeneous, data were either logarithmically or square root transformed or the non-parametric Kruskal- 
Wallis test was used (Zar, 1996; Dytham, 2003). The chi-square of the SPSS v.15.0 was used to test the hypothesis that the site and the studied niches in a crosstabulation were independent.

\section{RESULTS}

A total of 1799 larvae were collected from offshore and inshore sites, representing 63 taxa of 44 families belonging to 16 orders. Most larvae could be identified to different taxonomic levels; 27 taxa were identified to species, 17 taxa to genus and 19 taxa as family. These taxa were divided to three ecological niches which are expected to influence their distribution. These niches included the adult spawning mode, the adult habitat and the adult depth (Table 1).

Table (1).Species composition, abundance, and number of taxa in different spawning modes at offshore and inshore sites.

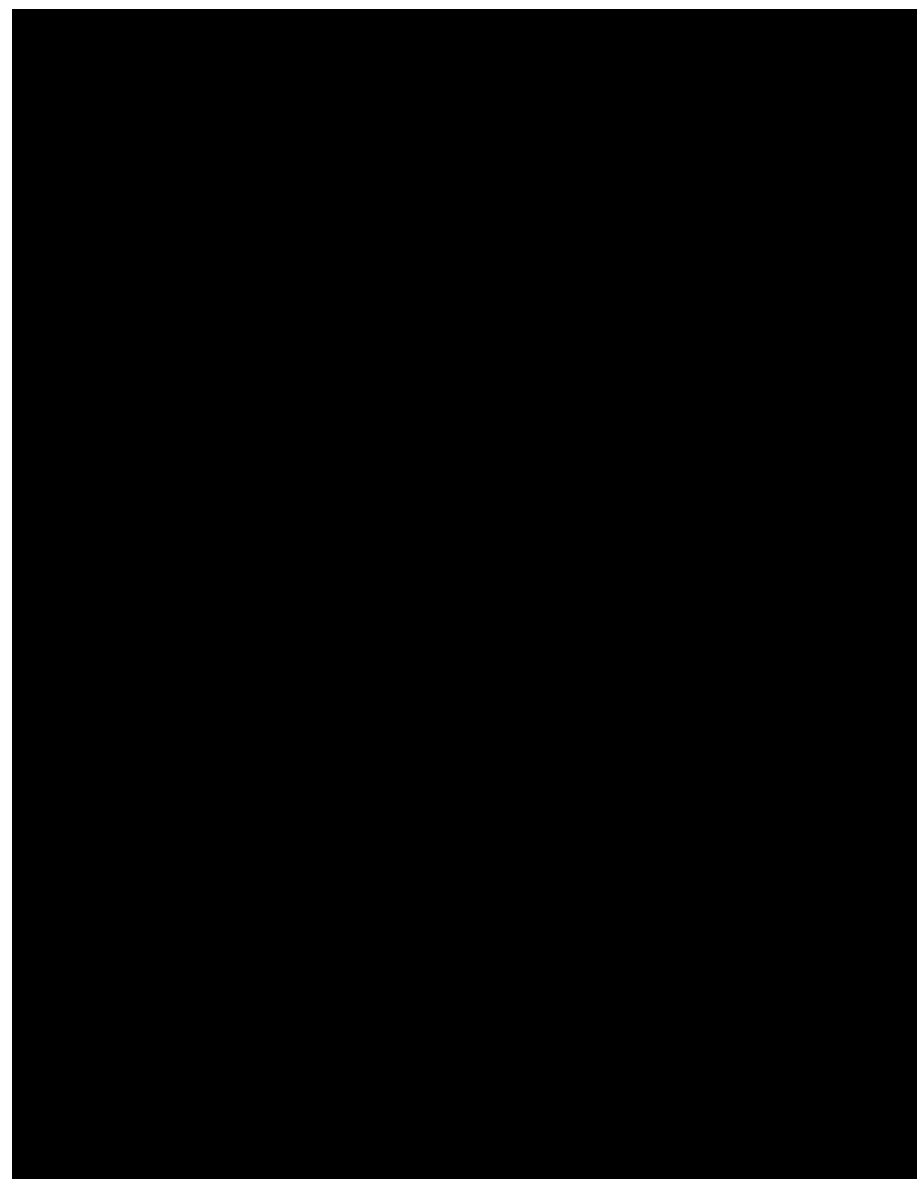




\section{Spawning mode}

Larvae of demersal spawners were the most abundant of all categories; forming $64.5 \%$ of all collected larvae, with an abundance of $383 / 1000 \mathrm{~m}^{3}$. Larvae of pelagic spawners were the second most abundant, forming 35\% with an abundance of $201.5 / 1000 \mathrm{~m}^{3}$ (Fig. 2a). Although demersal spawners were highly abundant, they were represented by fewer taxa (22), than the pelagic spawners (36) (Table1). Brooders and live-bearers were weakly represented by 4 taxa and 1 taxon forming 1.2 and $0.3 \%$, respectively (Table 1 ). Larvae from demersal spawners dominated the inshore sites, with 15 taxa compared to 12 pelagic taxa. On the contrary, larvae from pelagic spawners dominated the offshore sites with 27 taxa compared to 12 demersal taxa. The most abundant inshore species from pelagic eggs was Gerres oyena which was completely absent from offshore sites. Larvae from brooders were more abundant in the inshore sites (16\%) than in the offshore sites (4\%) (Figs. 2b, c). Brooders were represented by cardinalfishes, Apogon taeniatus and Cheilodipterus quinquelineatus, and seahorse Hippocampus sp. and live bearers were represented by the bythitid Dinematichthys iluocoeteoides.

The low significance value $(<0.05)$ indicates that there may be some relationship between the spawning mode of the adults and the distribution of the larval stages. The analysis of variance (ANOVA) indicated that the distribution of larvae from pelagic eggs varied significantly between inshore and offshore sites whereas those from the demersal eggs did not show any significant difference

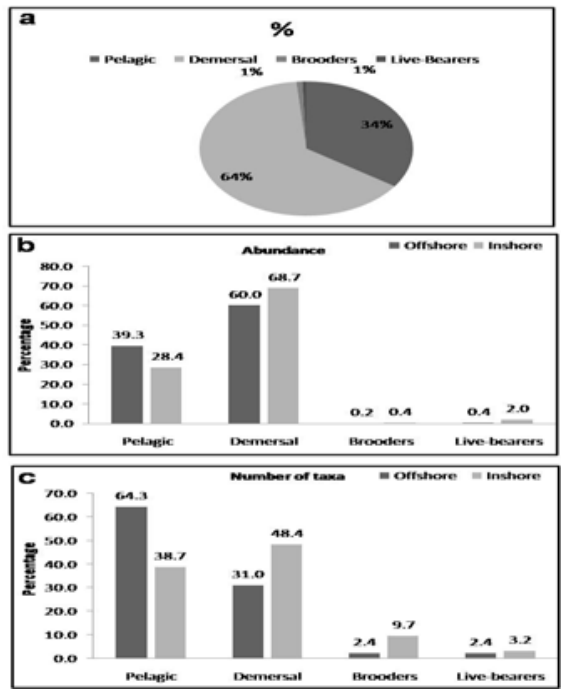

Fig.2. (a) Percentage contribution of different spawning modes.

(b) Abundance of larval fish from different spawning modes.

(c) Number of larval taxa from different spawning modes at the inshore and offshore sites.

\section{Habitat}


According to the adult habitats, fish larvae were divided into mesopelagic (oceanic) fishes and shore fishes, which have been in turn divided into reef fishes and non-reef fishes. Larvae of shorefishes were represented by 61 taxa, belonging to 42 families of which 36 families, including 52 taxa, were coral reef fishes. Larvae of coral reef fishes dominated the collection, with an abundance of 431 larvae $/ 1000 \mathrm{~m}^{3}$, constituting $72 \%$ of all collected larvae (Fig. 3a). They were more abundant at the inshore sites than the offshore sites with abundance of 238 larvae $/ 1000 \mathrm{~m}^{3}$ compared to 193 larvae $/ 1000 \mathrm{~m}^{3}$ in the offshore sites (Table2). Despite the lower abundance of reef fish larvae in the offshore sites, more taxa were taken. Larvae of 35 taxa of reef fish were collected from the offshore sites in comparison to larvae of 25 taxa at the inshore sites (Table 2).

Table (2). Species composition, abundance, and number of taxa in different adult habitats at offshore and inshore sites.

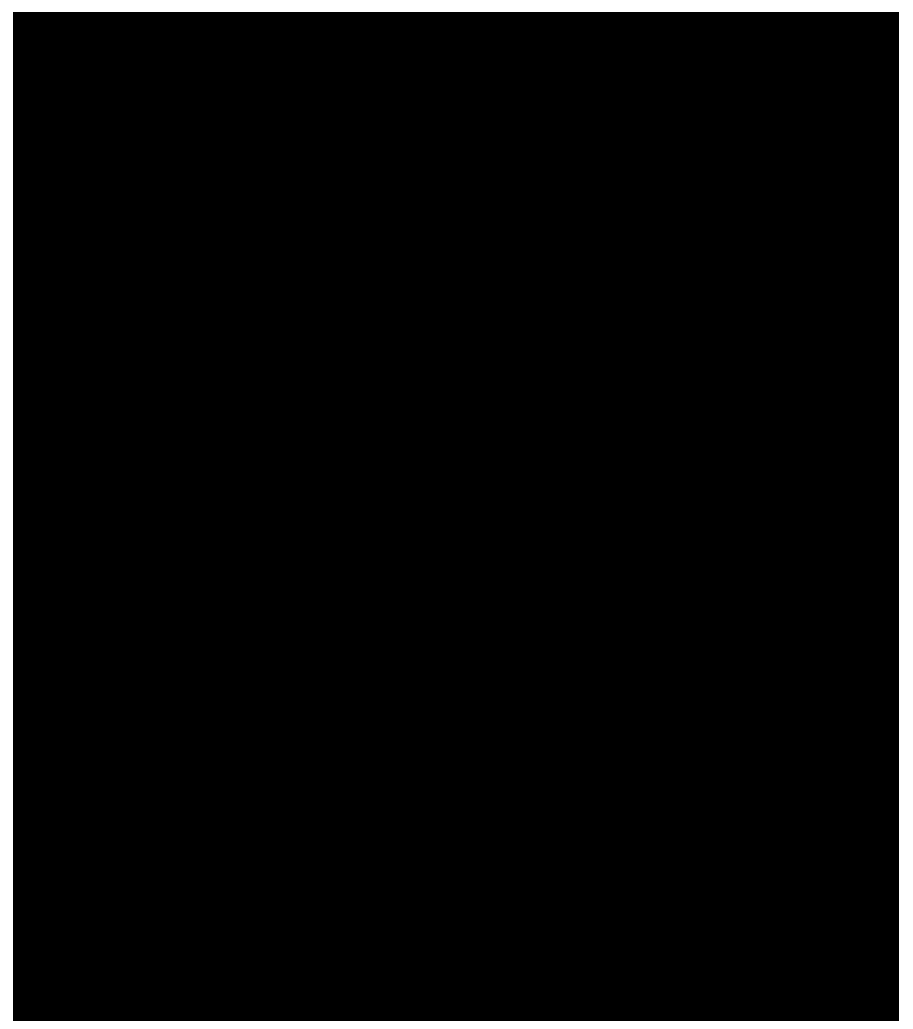

Larvae of 5 taxa of non-reef fishes forming $17 \%$ of all larvae were collected from all sites with a total abundance of 99.6 larvae $/ 1000 \mathrm{~m}^{3}$. They were more dominant at the inshore than the offshore sites, with abundance of 55 larvae $/ 1000 \mathrm{~m}^{3}$ and 44.6 larvae $/ 1000 \mathrm{~m}^{3}$, respectively. The number of taxa (5) was the same in inshore and offshore sites (Figs. 3b,c). 

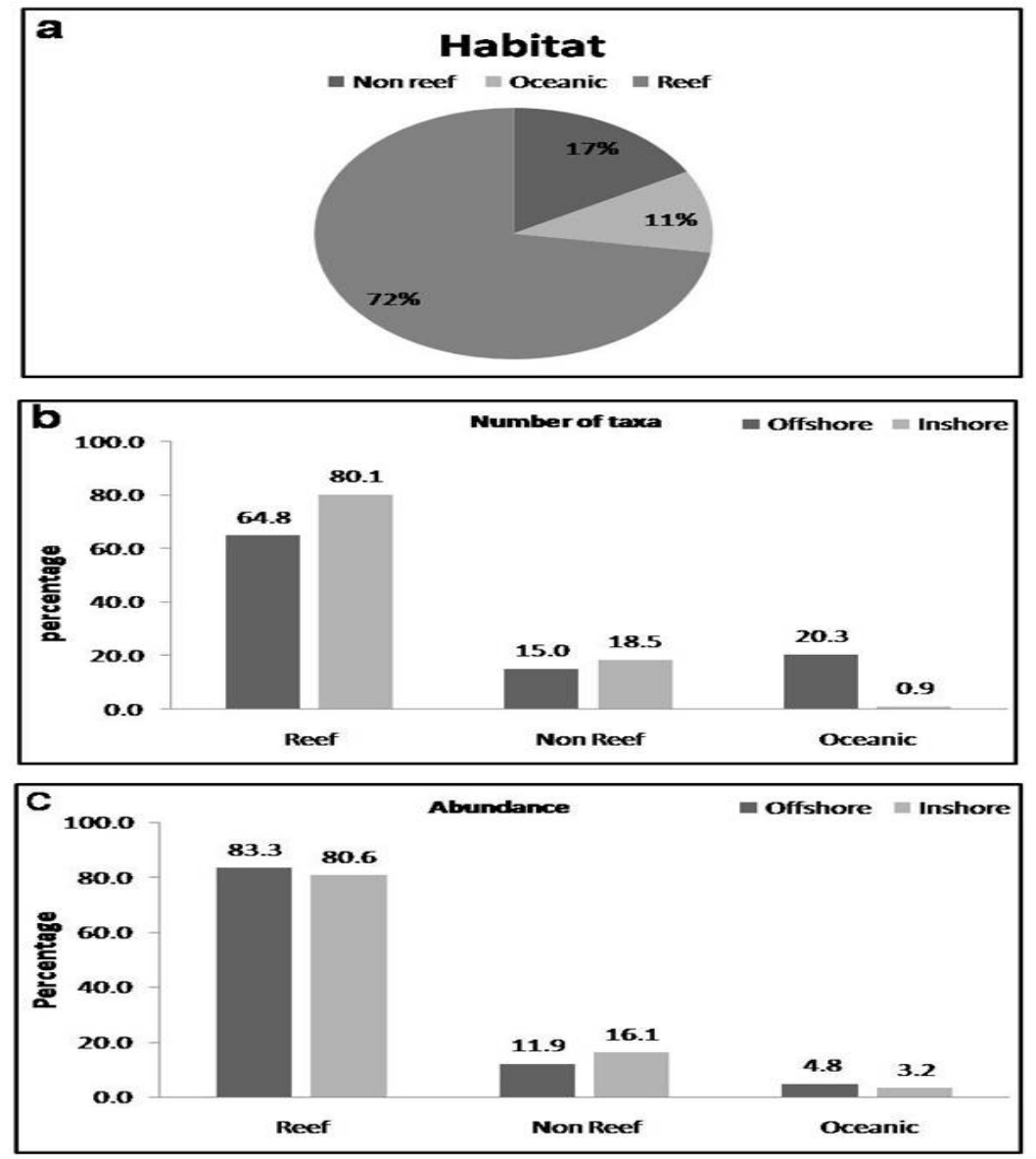

(a) Percentage contribution of different habitats.

Fig.3.

(b) Abundance of larval fish from different habitats.

(c) Number of larval taxa from different habitats at the inshore and offshore sites.

Mesopelagic fish larvae formed $11 \%$ of all recorded larvae, with a total abundance of 63.1 larvae $/ 1000 \mathrm{~m}^{3}$. They were more abundant offshore $(60.3$ larvae $\left./ 1000 \mathrm{~m}^{3}\right)$ than inshore $\left(2.8\right.$ larvae $\left./ 1000 \mathrm{~m}^{3}\right)$. In general, as indicated by the higher value $(>0.05)$ of the Chi square test, there was no relationship between location of the larvae and habitats of their adults. 


\section{Depth (Habits)}

Larvae of the pelagic fishes were the most abundant with a total abundance of 45.6 larvae $/ 1000 \mathrm{~m}^{3}$; followed by larvae of demersal fishes (215.8). Larvae from benthic fishes had the lowest abundance (132) (Fig. 4).

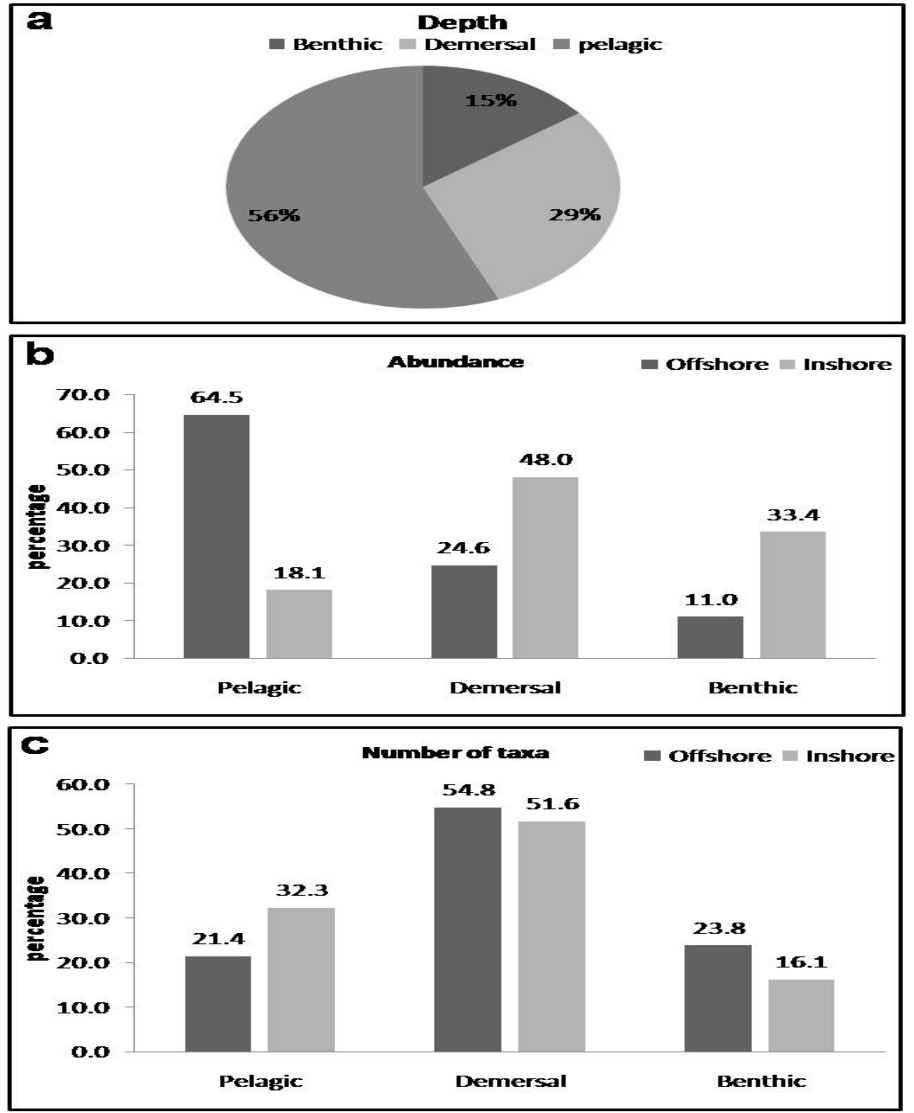

Fig.4. (a) Percentage contribution of different adult depths

(b) Abundance of larval fish from different adult depths.

(c) Number of larval taxa from different adult depths at the inshore and offshore sites.

Despite their high abundance at offshore sites, pelagic fish larvae were represented only by 9 taxa. They were more abundant at offshore than inshore sites. Demersal fish larvae were more abundant at inshore sites (142.7 larvae $\left./ 1000 \mathrm{~m}^{3}\right)$ than offshore sites $\left(73\right.$ larvae $\left./ 1000 \mathrm{~m}^{3}\right)$. They were represented by larvae of 37 taxa of which 23 taxa were taken at offshore and 16 taxa were taken at inshore sites. Two taxa, Mulloides flavolineatus and Enneapterygius sp. were collected at offshore and inshore. Benthic fishes showed the lowest abundance. Larvae of Gobiidae and Blennidae were good representatives of the 12 benthic taxa recorded during the study (Table 3). 
Table (3). Species composition, abundance, and number of taxa in different categories of adult depth at offshore and inshore sites.

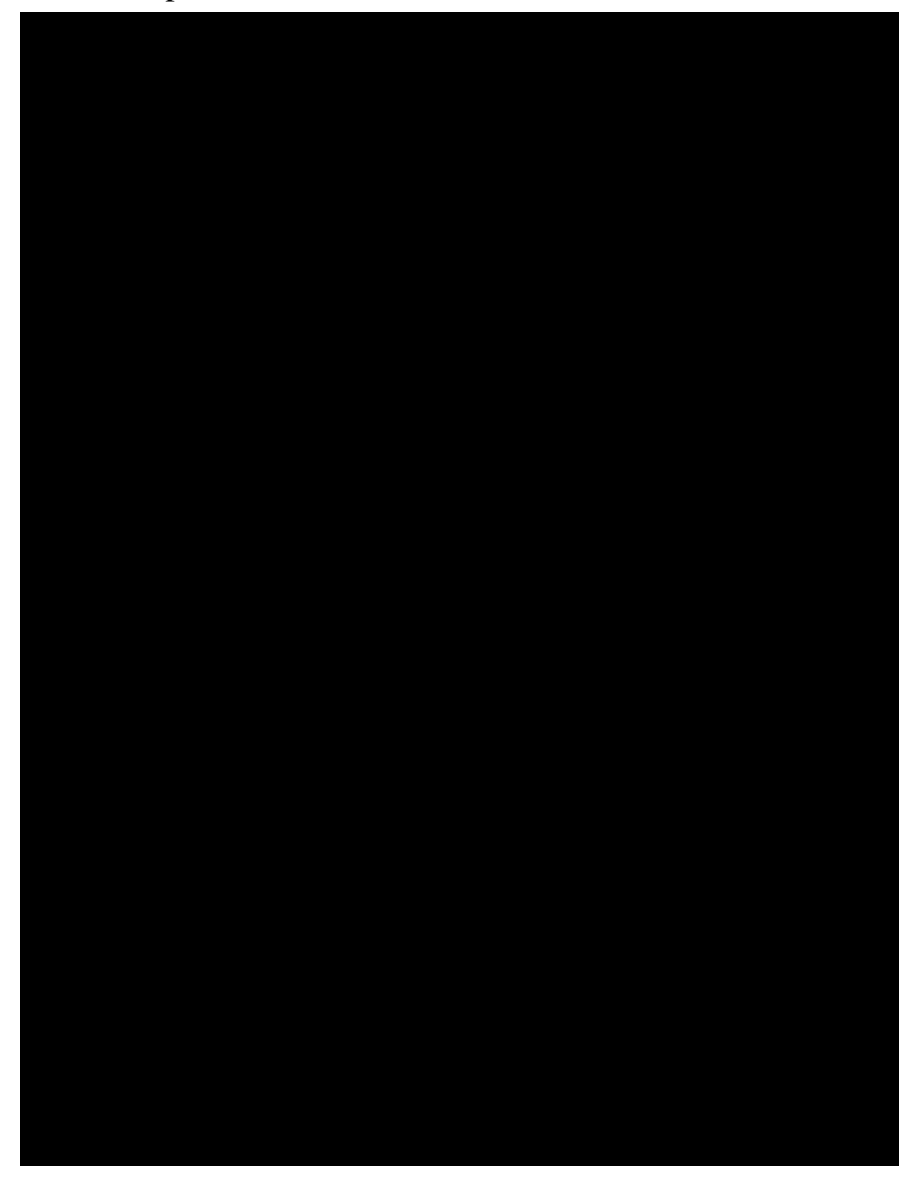

\section{DISCUSSION}

Measuring the dispersal of fish larvae is considered as the greatest challenge facing marine ecologists and managers (Jones et al., 2005). Larval distribution depends on a complex interaction between biological and physical factors that can strongly modify the distribution and abundance of larval stages (Harris et al., 1999). The distribution of fish larvae can be determined by spawning behavior of their adults, hydrography and topography of the reef, duration of larval period, behavior, growth and mortality of the larvae (Cushing, 1990; Leis, 1991a; Montgomery et al., 2001; Leis et al., 2006). The present study deals with the influence of some ecological niches of adults on the distribution of their larval stages.

The current study has shown that there were two assemblages of larvae with different distributions; inshore and offshore assemblages. The inshore 
assemblage was composed mainly of larvae of demersal spawners while the offshore assemblage composed mainly of larvae of pelagic spawners. This result is in a full agreement with findings of Leis (1982); Smith et al. (1987); Clarck, (1991); Suthers \& Frank (1991); Leis \& McCormic (2002); Paris and Cowen (2004). Brogan (1994) noted that larvae from demersal spawners are used to measure the larval retention. Leis $(1978,1982)$ showed that, the dominance of larvae of demersal species nearshore was due to a few species. In the present study, the high abundance of larvae of demersal spawners was due to the high larval density of families with demersal eggs such as Atherinidae and Clupeidae. Larvae of Atherinomorus lacunosus (Atherinidae) and Spratelloides delicatulus (Clupeidae) were very highly abundant at inshore and offshore sites, with a total abundance of $113 / 1000 \mathrm{~m}^{3}$ and $72 / 1000 \mathrm{~m}^{3}$ respectively.

Demersal spawners attach their eggs to corals, rocks or floating objects and some fishes (damselfishes and gobies) show parental care. They prefer the shallow, rocky, inshore areas near to the adult habitat (Azeiterio et al., 2006). This may explain the high diversity of demersal spawners at the inshore sites than the offshore sites in the present study. Larvae of 35 taxa were derived from pelagic spawners and larvae of 25 taxa came from demersal spawners. Most fishes on the reef are pelagic spawners (Leis, 1991); forming 78\% of all fishes on the reef whereas that of demersal spawners form $14 \%$ of all reef fishes in the Red Sea. In the current work the low significance value $(<0.05)$ indicates that the spawning mode of the adults influenced the distribution of the larval stages. This coincides with the finding of Montgomery et al. (2001) and Leis et al. (2006) that the distribution of larval stages can be determined by the spawning mode of the adults.

In the present work, the identified larvae were classified according to the adult habitat into reef, non reef and mesopelagic fish larvae. The larval fish assemblages in tropical waters are derived from spawning activities of reef fish and mesopelagic fishes (Ahlstrom, 1971; 1972; Leis \& Goldman, 1987). Coral reef fish larvae dominated samples from inshore (35 taxa, 83\%) and offshore (25 taxa, 80.6\%), although they were more diverse offshore. However, larvae of some important reef fish taxa were absent inshore and offshore. Brogan (1994) concluded that the absence of coral reef fish larvae offshore may be due to the short duration period of larvae of some taxa. Leis (1987) stated that larvae of some reef fish such as serranid and lutjanid were rare or totally absent because they are deep in the water column. Most notably, larvae of some families of reef fishes are missing inshore although they are abundant as adults. Despite the high abundance and diversity of Acanthuridae, Chaetodontidae, Scaridae, and Pomacanthidae as adults in the inshore area, their larvae were totally absent. The absence of larvae of some reef fishes inshore was also reported in other studies (Miller, 1974, 1979; Watson \& Leis, 1974; Young et al., 1986; Leis, 1994). Hence, the inshore larval assemblages may not be fully representative of the 
adult fish assemblage. The dispersal of larvae from the reef may be one reason for the absence of these larvae.

Of the non-reef fishes, larvae of the clupeid Spratelloides delicatulus, and the hemirhamphid Hyporhamphus gambrur, were dominant. The most common of the non-reef fish was Spratelloides delicatulus that formed $11 \%$ of all collected larvae. Larvae of mesopelagic fishes were abundant near the coral reef, which is in agreement with the findings of Leis (1991), who concluded that mesopelagic larvae may be drifted to the reef by water currents. Two mesopelagic species, $V$. mabahiss and B. pterotum, forming $5 \%$ and $1 \%$ of larvae collected, were recorded. The analysis of variance showed that the distribution of the mesopelagic species, Benthosema pterotum and Vinciguerria mabahiss varied significantly between inshore and offshore sites. Larvae of Benthosema pterotum larvae were totally absent at the inshore sites. Among the mesopelagic fishes whose larvae were absent from the present study was the family Scombridae that includes tunas.

The influence of where the adult fish lives in the water column on the distribution of larval stages is poorly studied. This study aimed to investigate whether the distribution of larvae can be related to the depth in the water column where their adults live. Although demersal and benthic fishes formed about 85\% of all fishes in the Red Sea (Goren \& Dor, 1994), their larvae were less abundant than that of the pelagic fishes. Larvae of the pelagic fishes can be drifted to the reef areas by current (Leis, 1991a). The most common pelagic fishes in the area of study were of family Clupeidae that constituted $11 \%$ of all larvae collected. Larvae of family Blennidae (benthic fishes) were also abundant in the shallow water at inshore area. Azeiterio et al. (2006) concluded that blennid larvae are more abundant at shallow areas inshore where they prefer to remain near intertidal shore adult habitat. The Chi square value $(>0.05)$ showed that the distribution of the larvae was independent on the depth at which their adults live.

It can be concluded from the present data that the distribution of the larvae near coral reefs at Hurghada may be dependent on the spawning mode of their adults but not on the other studied ecological issues.

Although distribution of fish larvae in the coral reef has received more attention than any other aspect of their biology, it is not yet fully understood. Good understanding of the physical processes in the area of investigation as well as the biological processes is urgently required. Physical studies are very expensive and are always ignored by biologists (Leis, 1991a). This study has provided further information on the distributional patterns of the larvae of coral reef fishes that help to understand the interrelationships among fish species during their larval stages. However, further studies are required to understand the patterns of dispersal of fish larvae in the area in relation to the other biological and physical factors. 


\section{REFERENCES}

Ahlstrom, E. H. (1971). Kinds and abundance of fish larvae in the eastern tropical Pacific, based on collections made on EASTROPAC I. Fish. Bull., 69(1): 3-77.

Ahlstrom, E. H. (1972). Kinds and abundance of fish larvae in the eastern tropical Pacific on the second multivessel EASTROPAC survey and observations on the annual cycle of larval cycle of larval abundance. Fish. Bull., 70(4): 1153-1242.

Azeiterio, U. M.; Resende, P.; Goncalves, F. and Pereira, M. J. (2006). Larval fish distribution in shallow coastal waters off North Western Iberia (NE Atlantic). Estuar. Coast. Shelf Sci., 64: 544-566.

Brogan, M. W. (1994). Distribution and retention of larval fishes near the reefs in the Gulf of California. Mar. Ecol. Prog. Ser., 115: 1-13

Clark, T. (1991). Larvae of nearshore fishes in oceanic waters near Oahu, Hawaii. NOAA Technical report NMFS, 101: 1-19

Cushing, D. H. (1990). Plankton production and year class strength in fish populations: an update of the match/mismatch hypothesis. In: Blaxter, J. H., Southward, A. J. (Eds.), Adv. Mar. boil. vol. 26. Academic Press, San Diego, pp. 249-293.

Dytham, C. (2003). Choosing and using statistics. A biologist's guide. Blackwell Publishing, Oxford, 248 pp.

Goren, M. and Dor, M. (1994). An updated checklist of the fishes of the Red Sea CLOFRESII. Israel Academy for Sciences and Humanities. The Israel Academy of Sciences and Humanities. Jerusalem, 120 pp.

Hernández-Miranda, E.; Palm, A.T. and Ojeda, E. P. (2003). Larval fish assemblages in nearshore coastal waters off central Chile: temporal and spatial patterns. Estuar. Coast. Shelf Sci., 5: 1075-1092.

Houde, E. D. and Zastrow, C. E. (1993). Ecosystem- and taxon-specific dynamic and energetics properties of larval fish assemblages, Bull. Mar. Sci., 53: 290-335. 
Jones, P. G. ; Thorrold, S. R. and Planes, S. (2005). Coral reef fish larvae settle close to home. Curr. Biol.., 15:1314 -1318.

Lazzari, M. A. (2001). Dynamics of larval fish abundance in Penobscot Bay, Maine. Fish. Bull., 99:81-93

Leis, J. M. (1982). Nearshore distributional gradients of larval fish (15 taxa) and planktonic crustaceans (6 taxa) in Hawaii. Mar. Biol., 77: 89-97.

Leis, J. M. (1987). Review of the early life history of tropical groupers (Serranidaea) and snappers (Lutjanidae). Pages. 189-237. In: J. J. Polovina and S. Rajston. 1987. Tropical snappers and groupers: Biology and Fisheries Management. Westview Press/ Boulder and London.

Leis, J. M. (1991a). The pelagic stage of reef fishes: The larval biology of coral reefs. In: Sale, P. F. the ecology of fishes on coral reefs. Academic press, pp. $183-230$

Leis, J. M. (1991b). Vertical distribution of fish larvae in the Great Barrier Reef lagoon, Australia. Mar. biol.,109: 157-166.

Leis, J. M. (1993). Larval fish assemblages near Indo-Pacific coral reefs. Bull. Mar. Sci., 53(2): 362-392.

Leis, J.M. (1994) Coral Sea atoll lagoons: closed nurseries for the larvae of coral reef fishes. Bull. Mar. Sci., 54(1): 6-227.

Leis, J. M. and Goldman, B. (1987). Composition and distribution of larval fish assemblages in the Great Barrier Reef Lagoon near Lizard Island, Australia. Aust. J. Mar. Freshwater Res., 38(2): 211-223.

Leis, J. M. and McCormick, M. I. (2002). The biology, behaviour, and ecology of the pelagic larval stage of coral reef fishes. In: Sale, P.F. (Ed), Coral reef fishes: dynamics and Diversity in a complex ecosystem. Academic press, San Diego. pp. 171-199.

Leis, J. M.; Hay, A. C. and Trnski, T. (2006). In situ ontogeny of behaviour in pelagic larvae of three temperate, marine, demersal fishes. Mar. Biol., 148: 655-669. 
Miller, J. M. (1974). Nearshore distribution of Hawaiian marine fish larvae: effects of water quality, turbidity and currents. In: "the early life history of fish” (J. H. S. Blaxter, ed), pp. 217-231. Springer-Verlag, New York.

Miller, J. M. (1979). Larval fish distribution. In" an atlas of common nearshore fish larvae of the Hawaiian Islands" (J.M. Miller, W. Watson and J.M. Leis), Misc. rep. 80-02,pp 105-152. Univ. of Hawaii Sea Grant program, Honolulu, Hawaii.

Montgomery, J. C.; Nicholas, T. and Haine, O.S. (2001). Active habitat selection by presettlement reef fishes. Fish Fish., 2:261-277.

Moser, H. G.; Richards, W. J.; Cohen, D. M.; Fahay, M. P.; Kendall, D. W.; Richardson, Jr.; S. L. ;eds. Ontogeny and systmatics of fishes. American. Society of Ichthyologists and Herpetologists. Special Publication 1.

Paris, C. and Cowen, R. k. (2004). Direct evidence of biophysical retention mechanism for coral reef fish larvae. Limnol. Oceanogr, 49: 19641979.

Smith, C. L.; Tyler, J. C. and Stillman, L. (1987). Inshore ichthyoplankton: a distinctive assemblage? Bull. Mar. Sci. 41: 432-440.

Sponaugle, S.; Cowen, R. K.; Morgan, S. G.; Leis, J. M.; Pineda, J.; Boehlert, G. W.; Kingsford, M. J.; Lindeman, K. C.; grimes, C. and Munro, J. L. (2002). Predicting self-recruitment in marine populations: biophysical correlates and mechanisms. Bull. Mar. Sci., 70:341-374.

Suthers, M. and Frank, K. T. (1991). Comparative persistence of marine fish larvae from pelagic versus demersal eggs off south-western Nova Scotia, Canada. Mar. Biol., 108: 175-184

Watson, W. and Leis, J. M. (1974). Ichthyoplankton of Kaneohe Bay, Hawaii: a one-year study of fish eggs and larvae. Univ. Hawaii Sea Grant Program Technical Report, 75:01-178

Young, P. C.; Leis, J. M.; and Hausfeld, H. F. (1986). Seasonal and spatial distribution of fish larvae in waters over the North West Continental Shelf of Western Australia. Mar. Ecol. Prog. Ser., 31: 209-222. 
Zar, J. H. (1996). Biostatistical analysis. Fourth Edition. Prentice Hall International (UK), London. 